\title{
Participatory modelling
}

\author{
Géraldine Abrami, William's Daré, ${ }^{2}$ \\ Raphaëlle Ducrot, ${ }^{1}$ Nicolas Salliou ${ }^{3}$ and Pierre Bommel ${ }^{2}$ \\ ${ }^{1}$ BRGM, CIRAD, IRD, INRAE, INSTITUT AGRO, MONTPELLIER, FRANCE \\ ${ }^{2}$ CIRAD, UR GREEN 47, MUSE UNIVERSITY OF MONTPELLIER, MONTPELLIER, FRANCE \\ ${ }^{3}$ DEPARTMENT OF CIVIL, ENVIRONMENTAL AND GEOMATIC ENGINEERING, INSTITUTE FOR SPATIAL AND \\ LANDSCAPE DEVELOPMENT, PLANNING OF LANDSCAPE AND URBAN SYSTEMS (PLUS), \\ ETH ZÜRICH, ZÜRICH, SWITZERLAND
}

\section{Key methods discussed in this chapter}

Modelling methods: System dynamics (group model building, mediated modelling, shared vision planning), agent-based models (ARDI), role-playing games (Wat-A-Game), expert models (Bayesian networks, fuzzy cognitive maps), state-and-transition models, soft system methodologies (rich pictures, concept maps, decision trees, cognitive maps)

Integrated approaches: Collaborative modelling, companion modelling, participatory system analysis

\section{Connections to other chapters}

Methods for generating data and systems scoping (Chapters 5-8), specifically participatory data-collection methods (Chapter 8) or interviews and surveys (Chapter 7), may provide working material or monitoring and evaluation support within participatory modelling processes. Facilitated dialogue methods (Chapter 9) may smooth participatory modelling workshops. Future analysis (Chapter 10), scenario development (Chapter 11) or serious games (Chapter 12) may be articulated with participatory models within broader participatory resilience assessment (Chapter 14) or action research (Chapter 15) projects. Expert modelling (Chapter 16), dynamical systems modelling (Chapter 26), state-and-transition modelling (Chapter 27) and agent-based modelling (Chapter 28) cover the most common types of modelling methods used in participatory modelling, and participatory modelling may use institutional analysis (Chapter 22) conceptual frameworks.

\section{Introduction}

Whatever the purpose of a model, e.g. forecasting, prescription, explanation, description, learning and communication or theory building (Kelly et al. 2013; Schlüter, Müller, and Frank 2019), participatory modelling refers to settings where non-scientist stakeholders are involved in any of the stages of the modelling process of their social-ecological systems (SES). 


\begin{tabular}{|c|c|}
\hline \multicolumn{2}{|c|}{ SUMMARY TABLE: PARTICIPATORY MODELLING } \\
\hline DISCIPLINARY BACKGROUND & KNOWLEDGE TYPE \\
\hline $\begin{array}{l}\text { The methods in this chapter are derived } \\
\text { from or have most commonly been used in: } \\
\text { Environmental Management, (soft) } \\
\text { Operational Research, Complex Systems } \\
\text { Science }\end{array}$ & $\begin{array}{l}\text { The methods in this chapter are primarily } \\
\text { used to generate the following types of } \\
\text { knowledge: } \\
\text { - Descriptive } \\
\text { - Exploratory } \\
\text { - Explanatory }\end{array}$ \\
\hline RESEARCH APPROACH & PURPOSE OF METHOD \\
\hline $\begin{array}{l}\text { The methods in this chapter originate } \\
\text { from or most commonly adopt the } \\
\text { following research approaches: } \\
\text { - Interpretive/subjective } \\
\text { - Collaborative/process }\end{array}$ & $\begin{array}{l}\text { The most common purposes of using the } \\
\text { methods in this chapter are: } \\
\text { - System understanding } \\
\text { - Stakeholder engagement and } \\
\text { co-production } \\
\text { - Policy/decision support }\end{array}$ \\
\hline TEMPORAL DIMENSION & SYSTEMIC FEATURES AND PROCESSES \\
\hline $\begin{array}{l}\text { The methods in this chapter are most } \\
\text { commonly applied to the following } \\
\text { temporal dimensions: } \\
\text { - Present (typically within the last } \\
5-10 \text { years) } \\
\text { - Recent past (post-1700s) } \\
\text { - Future }\end{array}$ & \multirow{3}{*}{$\begin{array}{l}\text { While most methods can do many } \\
\text { things, the methods in this chapter are } \\
\text { particularly good (i.e. go-to methods) for } \\
\text { addressing the following: } \\
\text { - Diversity } \\
\text { - Social-ecological dependence } \\
\text { and impact } \\
\text { - Social learning } \\
\text { - Collective action and collaborative } \\
\text { governance } \\
\text { - Evaluating policy options }\end{array}$} \\
\hline SPATIAL DIMENSION & \\
\hline $\begin{array}{l}\text { The methods in this chapter are primarily } \\
\text { either or both: } \\
\text { - Non-spatial } \\
\text { - Explicitly spatial } \\
\text { The methods in this chapter are most } \\
\text { commonly applied at the following } \\
\text { spatial scales: } \\
\text { - Local } \\
\text { - Multiple places/sites around the world }\end{array}$ & \\
\hline
\end{tabular}


In the 1960s and 1970s, participatory modelling was rooted in the development of system dynamics models (Voinov and Bousquet 2010; Barreteau et al. 2013). At the time, business models were co-developed with business managers at MIT, and citizens were involved by the US Army Corps of Engineers in environmental management by using system dynamics modelling. Various schools of research have since developed consistent principles, practices and methods for modelling and participation, such as participatory simulation (complexity and computer science), collaborative learning (education science), social sciences experiments (experimental economics) or participatory action research. The field of water management is particularly rich in reflections on participation and modelling (Harmonicop Team 2005; Pahl-Wostl et al. 2007; Basco-Carrera et al. 2017).

Stakeholders may be involved in a modelling process to address issues related to the understanding, representation and management of SES, such as water basins, fisheries or forests. Using modelling stimulates knowledge elicitation and creative thinking (Jordan et al. 2018; Van Bruggen, Nikolic, and Kwakkel 2019). Models act as boundary objects by providing explicit and negotiable representations of reality (Star and Griesemer 1989). From a technical perspective, participatory modelling assumes that, within an appropriate interaction setting, non-specialists are able to co-produce models which make sense to them and which generate useful discussions and new knowledge.

\section{SES problems and questions}

Questions related to social-ecological systems can be classified according to three rationales for engaging in participatory modelling, as identified by Barreteau et al. (2013).

1. Assuming that the integration of various kinds of knowledge is useful for understanding and managing SES, participatory modelling may be used to increase the intrinsic quality of SES models by addressing questions such as:

- How does one deal with knowledge gaps and ambiguities? (e.g. using modelling to gather and discuss disparate elements of knowledge from users and managers to reduce uncertainties on complex dynamics (Barreteau et al. 2013))

- How does one calibrate and validate a model of an SES? (e.g. using a role-playing game as a participatory simulation setting to involve lay stakeholders in the validation of an agent-based model of their system (Barreteau, Bousquet, and Attonaty 2001) or having heterogeneous groups of stakeholders 'suggest and check' a model of their system in workshops (Polhill, Sutherland, and Gotts 2009))

2. Assuming that the involvement of stakeholders, including decision-makers, in the production and spreading of models increases the legitimacy, relevance and impact of these models through the collaborative framing and design of assumptions, elements, outputs and settings (Hare 2011), participatory modelling may improve the adequacy of models in aiding SES management:

- How does one frame model boundaries, questions and outputs to be relevant to real-world issues? (e.g. organising meetings to discuss and reformulate issues among actors that have divergent stakes and interests in SES (Dewulf, Bouwen, and Taillieu 2006))

- How does one design and explore management options? (e.g. using participatory simulation sessions with decision-makers, managers and economic actors to examine and virtually test options (Souchère et al. 2010)) 
- How does one improve appropriation of a model? (e.g. actively involving future users all along the framing, development and deployment of a decision-support system (Jakku and Thorburn 2010))

3. Assuming that the acknowledgement of non-scientific norms, values and interests, and the empowerment of stakeholders are assets for more sustainable transformations and policy pathways of SES (Van Bruggen, Nikolic, and Kwakkel 2019), participatory modelling may be used to support larger processes:

- How does one engage stakeholders in a shared systemic vision of their SES? (e.g. by engaging them in a full-cycle collaborative modelling process (Langsdale et al. 2013))

- How does one induce more informed collective decisions? (e.g. through recognising, accepting and exploring uncertainties and ambiguities during the co-design of a model (Salliou et al. 2017))

- How does one increase the ability of stakeholders to participate in SES governance arenas? (e.g. by using participatory modelling settings to raise the cognitive and deliberative capacities of participants (Daré et al. 2018; Landström et al. 2019))

- How does one deal with divergent representations? (e.g. by collectively discussing models based on stakeholder heuristics versus science-based models (Smajgl et al. 2015))

- How does one improve communication among stakeholders? (e.g. by using models resulting from participatory modelling to communicate stakeholders' views among different organisational levels (Daniell et al. 2010))

- How does one improve deliberation among stakeholders? (e.g. by using models as boundary objects to allow users and managers to negotiate indicators and set a new basis for joint resource management (Barreteau et al. 2012))

- How does one induce social learning? (e.g. by using group model building to improve the problem-solving capacities of a collective (Vennix 1996))

\section{Brief description of key methods}

Participatory modelling is commonly centred on the model information, construction and use stages. However, genuine participation requires one to involve stakeholders early in the modelling process, i.e. during the preparation and organisation stages (including framing and participant selection), all the way to the follow-up stages (including dissemination, monitoring and evaluation). The engagement level varies from observation to co-steering among the different stages and stakeholders. A synthetic description framework described by Bots and Van Daalen (2008) or a participatory engineering method such as the PrePar tool (Ferrand et al. 2017) is useful for planning and reflecting on these processes.

Depending on the characteristics and stage of development of the model, each participatory modelling event has distinct purposes, e.g. to provide advice, clarify the vision, mediate conflicting views or improve the model (e.g. see Bots and Van Daalen 2008; Basco-Carrera et al. 2017). The design of the event should respond to these constraints through organising working groups (size, homogeneity, functioning, rules) for the different activities and choosing participatory settings (e.g. knowledge elicitation with conceptual diagrams or model verification with interactive simulations - see Hare (2011) for an overview). Refer to Voinov et al. (2018) for an extended discussion and guidelines for choosing participatory modelling methods and tools. Hare (2011), Voinov et al. (2016), and Van Bruggen, Nikolic and Kwakkel (2019) also provide lists and descriptions of the 
Table 13.1 Summary of key modelling methods used in participatory modelling

\begin{tabular}{|c|c|c|}
\hline Method & Description & References \\
\hline $\begin{array}{l}\text { System } \\
\text { dynamics }\end{array}$ & $\begin{array}{l}\text { System dynamics (SD) represent global state variable } \\
\text { dynamics and interdependences and are useful to reflect } \\
\text { on global system concepts. Graphical methods of SD } \\
\text { (causal loop diagrams and stock and flow diagrams) are } \\
\text { good for participatory system thinking and conceptual } \\
\text { SD model building. Many available computerised SD } \\
\text { tools (e.g. Vensim, Stella) navigate transparently between } \\
\text { diagrams, equations and simulation outputs. }\end{array}$ & $\begin{array}{l}\text { Key introductory text } \\
\text { Costanza and Ruth } \\
1998 \\
\text { Applications to SES } \\
\text { Sandker et al. 2010; } \\
\text { Stave } 2010\end{array}$ \\
\hline \multirow[t]{2}{*}{$\begin{array}{l}\text { Agent-based } \\
\text { models }\end{array}$} & $\begin{array}{l}\text { Agent-based models (ABMs) represent autonomous entities } \\
\text { interacting within spatially explicit levels of organisation. } \\
\text { These models are good for heterogeneous knowledge } \\
\text { integration because of their close ontological resemblance } \\
\text { to the real world. ABMs do not have a specific graphical } \\
\text { method. The ARDI (Actors, Resources, Dynamics and } \\
\text { Interaction) methodology offers a set of ad hoc diagrams } \\
\text { for ABM co-construction. Simplified versions of the unified } \\
\text { modelling language (UML) can also be used in participatory } \\
\text { settings (see Case study 13.1). }\end{array}$ & $\begin{array}{l}\text { Key introductory texts } \\
\text { Barreteau, Bousquet, } \\
\text { and Attonaty } 2001 \\
\text { (ABMs and RPGs); } \\
\text { Bousquet and Le Page } \\
\text { 2004; } \\
\text { Le Page and Bommel } \\
2005 \text { (UML for ABMs); } \\
\text { Etienne, Du Toit, and } \\
\text { Pollard } 2011 \text { (ARDI) }\end{array}$ \\
\hline & $\begin{array}{l}\text { ABMs are implemented and simulated with computer } \\
\text { platforms or role-playing games (RPGs). Cormas (cormas. } \\
\text { cirad.fr) and Netlogo (ccl.northwestern.edu/netlogo) are } \\
\text { free ABM platforms that provide features for participatory } \\
\text { simulations or computerised RPG. }\end{array}$ & $\begin{array}{l}\text { Applications to SES } \\
\text { Forrester et al. 2014; } \\
\text { Hoch et al. 2015; } \\
\text { Smajgl et al. } 2015\end{array}$ \\
\hline $\begin{array}{l}\text { Expert } \\
\text { modelling: } \\
\text { Bayesian } \\
\text { networks and } \\
\text { fuzzy cognitive } \\
\text { maps }\end{array}$ & $\begin{array}{l}\text { Expert modelling approaches mimic expert thinking. } \\
\text { Bayesian networks (BNs) represent the conditional } \\
\text { probabilities between variables states. Fuzzy cognitive } \\
\text { maps (FCMs) represent causal probabilities propagation } \\
\text { between factors. They have simple graphical formalisms } \\
\text { that are well suited to participatory settings and are } \\
\text { good for coping with variability or divergent opinion and } \\
\text { discussing variables or factors and their relationships. } \\
\text { Specific methods are available for participative } \\
\text { quantification or semi-quantification of probabilities or } \\
\text { influences (Das 2004). Netica (norsys.com/netica.html) } \\
\text { or Mental Modeler (mentalmodeler.org) are platforms to } \\
\text { construct and simulate BNs or FCMs. }\end{array}$ & $\begin{array}{l}\text { Key introductory texts } \\
\text { Düspohl, Zacharias, } \\
\text { and Doell } 2012 \text { (BNs); } \\
\text { Gray et al. } 2015 \\
\text { (FCMs) } \\
\text { Applications to SES } \\
\text { Kok 2009; } \\
\text { Celio and Grêt- } \\
\text { Regamey 2016; } \\
\text { Htun et al. } 2016 \\
\text { (FCMs); } \\
\text { Salliou et al. } 2017 \\
\text { (BNs) }\end{array}$ \\
\hline $\begin{array}{l}\text { Soft systems } \\
\text { methodologies }\end{array}$ & $\begin{array}{l}\text { Soft systems methodologies are modelling approaches } \\
\text { developed specifically for human-centred systems in the } \\
\text { field of management sciences. They provide graphical } \\
\text { methods that can be used alone or in a conceptual } \\
\text { stage of most of the models mentioned above, such } \\
\text { as concept maps (representation of concepts and } \\
\text { semantic relationships within a knowledge domain), } \\
\text { decision trees (representation of objectives, actions and } \\
\text { system uncertainties and evolution) or cognitive maps } \\
\text { (representation of causal or influence relationships). }\end{array}$ & $\begin{array}{l}\text { Key introductory text } \\
\text { Vidal } 2006 \\
\text { Applications to SES } \\
\text { Mendoza and Prabhu } \\
2006 ; \\
\text { Hommes et al. } 2008\end{array}$ \\
\hline
\end{tabular}


various tools and methods, computerised or not, that may be used for implementing participatory settings.

Because of their expressivity, model paradigms that are most broadly used in participatory modelling of SES are system dynamics models, agent-based models, expert modelling approaches and soft system methodologies (Table 13.1). State-and-transition models are another kind of modelling approach focusing on alternative states, thresholds and transitions (see Chapter 27). Furthermore, any type of model may be developed or used participatively within appropriate processes and settings (see Landström et al. 2019 for a pragmatic approach to participatory hydrological modelling). The relevance of a modelling method depends on the characteristics of the target system and on the available resources in terms of time, skills, money and data. In this regard, criteria and guidelines can be found in Schlüter, Müller and Frank (2019) and Kelly et al. (2013).

Communities of researchers and practitioners developed integrated approaches that provide methodological guidelines and tools for implementing a participatory modelling process (see Van Bruggen, Nikolic and Kwakkel 2019 for a comparative description). Some of the most well known are described in Table 13.2.

Table 13.2 Summary of key integrated approaches used in participatory modelling

\begin{tabular}{|c|c|c|}
\hline Approach & Description & References \\
\hline $\begin{array}{l}\text { Participatory } \\
\text { system analysis }\end{array}$ & $\begin{array}{l}\text { Participatory system analysis combines a broad } \\
\text { range of tools and techniques developed in } \\
\text { the field of systems thinking with participatory } \\
\text { methods. It is presented as an approach } \\
\text { that extends participatory rural assessment } \\
\text { with system science approaches. It provides } \\
\text { guidelines and tools for performing needs } \\
\text { and problems analysis, carrying out abstract } \\
\text { modelling, exploring decisions or scenario } \\
\text { options, and implementing design (maps, } \\
\text { spidergrams, Bayesian networks, system } \\
\text { dynamics, plans). }\end{array}$ & $\begin{array}{l}\text { Key introductory text } \\
\text { Lynam } 2001 \\
\text { Applications to SES } \\
\text { Smith, Felderhof, and Bosch } \\
\text { 2007; } \\
\text { Nguyen and Bosch } 2013\end{array}$ \\
\hline $\begin{array}{l}\text { Group model } \\
\text { building and } \\
\text { mediated } \\
\text { modelling }\end{array}$ & $\begin{array}{l}\text { Group model building (GMB) and mediated } \\
\text { modelling (MM) are historical integrated } \\
\text { approaches of participatory system dynamics } \\
\text { models building. Group model building focuses } \\
\text { on organisational messy problems and strategic } \\
\text { decision-making within teams. It provides } \\
\text { 'scripts' for standardised protocols (Hovmand } \\
\text { et al. 2012) and has been widely used in private } \\
\text { and public institutions. Mediated modelling } \\
\text { aims at involving broad stakeholder groups in } \\
\text { collective learning and consensus building on } \\
\text { environmental issues. It provides a structured } \\
\text { iterative process for involving the participants } \\
\text { between the distinct stages of model } \\
\text { development. }\end{array}$ & $\begin{array}{l}\text { Key introductory texts } \\
\text { Andersen et al. } 2007 \text { (GMB); } \\
\text { Metcalf et al. } 2010 \text { (MM) } \\
\text { Applications to SES } \\
\text { Antunes, Santos, and Videira } \\
2006 \text { (MM); } \\
\text { Daniell et al. 2010; } \\
\text { Halbe, Pahl-Wostl, and } \\
\text { Adamowski } 2018 \text { (GMB) }\end{array}$ \\
\hline
\end{tabular}




\begin{tabular}{|c|c|c|}
\hline Approach & Description & References \\
\hline $\begin{array}{l}\text { Shared vision } \\
\text { planning and } \\
\text { collaborative } \\
\text { modelling for } \\
\text { decision support }\end{array}$ & $\begin{array}{l}\text { Collaborative modelling for decision support } \\
\text { (CMDS) comprises collaborative system } \\
\text { dynamics modelling in combination with } \\
\text { communication, visualisation and facilitation } \\
\text { tools of structured public participation, and } \\
\text { mental and cultural models of planning } \\
\text { and decision support. It is based on the } \\
\text { experience of US government environmental } \\
\text { agencies on stakeholders' involvement in } \\
\text { water management. It is an evolution of the } \\
\text { US Army Corps of Engineers' shared vision } \\
\text { planning (SVP), which defines iterative steps } \\
\text { for participatory system dynamics modelling. } \\
\text { It is supported by principles and best } \\
\text { practices established by the joint work of a } \\
\text { community of academics and practitioners } \\
\text { of modelling, facilitation and water } \\
\text { management between } 2008 \text { and } 2010 \text {. }\end{array}$ & $\begin{array}{l}\text { Key introductory texts } \\
\text { Werick } 1994 \text { (SVP); } \\
\text { Langsdale et al. } 2013 \text { (CMDS); } \\
\text { Online sources (principles } \\
\text { and guidelines for SVP and } \\
\text { CMDS, e.g. labs.wsu.edu/ } \\
\text { collaborativemodeling/cmds) } \\
\text { Applications to SES } \\
\text { Palmer et al. 1999; } \\
\text { Antunes, Santos, and Videira } \\
\text { 2006 (MM); } \\
\text { Creighton and Langsdale } 2009 \\
\text { (SVP); } \\
\text { Basco-Carrera et al. } 2017 \\
\text { (CMDS) }\end{array}$ \\
\hline $\begin{array}{l}\text { Companion } \\
\text { modelling }\end{array}$ & $\begin{array}{l}\text { Companion modelling (ComMod) } \\
\text { promotes the iterative, collaborative and } \\
\text { adaptive use of models aimed at sharing } \\
\text { and legitimating multiple views of SES and } \\
\text { articulating scientific production and collective } \\
\text { decision-making. It mostly uses the agent-based } \\
\text { model paradigm with alternative or combined } \\
\text { use of role-playing games. It emerged in France } \\
\text { in the 1990s as an approach for implementing } \\
\text { complexity thinking and post-normal theory } \\
\text { (Funtowicz and Ravetz 1993) in natural } \\
\text { resources management issues. } \\
\text { ComMod has an active community of } \\
\text { researchers and practitioners hosting regular } \\
\text { events and training. Various tools and } \\
\text { methods, such as ARDI and Cormas, have } \\
\text { been developed (see 'Agent-based models' in } \\
\text { Table 13.1). } \\
\text { ComMod has also produced spin-off thematic } \\
\text { participatory modelling platforms. TerriStories } \\
\text { (terristories.org) offers a configurable board } \\
\text { game on land issues that combines concepts } \\
\text { from participatory modelling, role-playing } \\
\text { games and live theatre. Wat-A-Game is } \\
\text { a platform for the 'design by playing' of } \\
\text { games on water management. It is part of } \\
\text { CoOPLAaGE (cooplaage.watagame.info), a } \\
\text { larger integrated suite of low-tech tools and } \\
\text { protocols based on participatory modelling } \\
\text { of decision procedures. }\end{array}$ & $\begin{array}{l}\text { Key introductory text } \\
\text { Barreteau et al. } 2003 \\
\text { (ComMod charter) } \\
\text { Applications to SES } \\
\text { Souchère et al. 2010; } \\
\text { Abrami et al. } 2012 \\
\text { (CoOPLAaGE); } \\
\text { d'Aquino and Bah 2013; } \\
\text { Hassenforder et al. 2015; } \\
\text { Bouamrane et al. 2016; } \\
\text { Ferrand et al. 2017; } \\
\text { Ponta et al. 2019; } \\
\text { commod.org (case studies and } \\
\text { material) }\end{array}$ \\
\hline
\end{tabular}




\section{Limitations}

The intrinsic quality of participatory models is highly dependent on how the participation is organised. Biases and interests of participants (including modellers and researchers) may have an impact on the scope and elements of the model, which needs to be carefully considered (Daniell et al. 2010). Skilled facilitation and negotiation are necessary. Special care should be taken with graphical computerised tools because the ease of adding new elements can quickly lead to overly complex models (Kelly et al. 2013).

Participatory modelling may raise false expectations or can be deceptive. Participants may feel that the final model does not represent their views adequately, particularly after some post-processing work (Daniell et al. 2010; Hare 2011). They may perceive it as too narrow or too complex relative to the richness of the modelling process (Sandker et al. 2010). Conceptual models based on stakeholder perspectives may not make sense outside the participation arena, and decision-makers may not need a new integrated model but rather simple, data-rich and trustworthy models that can be used for decision support (Hare 2011). These risks are high when participation happens within several interconnected processes sharing part or all of their teams, participants and events, but each having its own agenda and objectives (Seidl 2015). The risks can be minimised by carefully considering the expectations, purposes and agendas of participants, clients and organising team, and also by designing and communicating as explicitly and transparently as possible about the processes, their outcomes and products, and how they will be shared or used (Sterling et al. 2019). If model uptake is an objective, an answer can be to choose off-the-shelf software that is easy to learn and available to all (Langsdale et al. 2013), or to plan for professional levels of model documentation and maintenance in the project funding (Hare 2011).

Participatory modelling may lead to undesirable effects for the process and for the participants. The framing induced by the model may inhibit deliberation and creativity rather than fostering it (Barnaud and Van Paassen 2013). Hedelin et al. (2017) warn that the modelling may induce a focus on the choice of measures ('How can we get there?') rather than on broader issues of societal development ('Where do we want to go?'). The question of how the modelling approach (modelling method, level of realism, level of integration) is chosen and how it affects the modelling process output and participants is discussed in Langsdale et al. (2013), Le Page and Perrotton (2017), and Schlüter, Müller and Frank (2019). Regarding ethics, inappropriate consideration of participants' motivation or power asymmetries may create biases in the model or harmful impacts in the 'real world' (Barnaud and Van Paassen 2013; Daré and Venot 2017; Hedelin et al. 2017). See for instance criticisms and hints from a socio-political perspective in Tsouvalis and Waterton (2012).

The impact of participatory modelling in larger SES transformation processes may appear limited or difficult to assess. The size of the co-modelling groups and the time frame of research projects are limiting factors. This implies that process extension may be needed to achieve transformative effects (Hare 2011). Joint ownership of an associate decision-making process is an asset in this regard (Van Bruggen, Nikolic, and Kwakkel 2019). Landström et al. (2019) propose a systematic approach to consolidate participants' commitment during and after the project. Extension through widespread adoption of participatory modelling outside research projects is limited not only by low binding participatory obligations but also by the limited human capacity (skills and personnel) of local communities and management institutions (Hare 2011). The monitoring and impact assessment of participatory modelling raises specific questions in data collection and analysis, which requires more research (Jones et al. 2009; Smajgl and Ward 2015; Hassenforder et al. 2016). 
Finally, even though participatory modelling case studies have flourished in the past 20 years, the field still lacks common sets of principles and frameworks or roadmaps that would unify existing approaches sharing the same goal. This would support the design of new participatory modelling processes, structure analysis and evaluation of past cases (Jordan et al. 2018; Van Bruggen, Nikolic, and Kwakkel 2019). Generic templates would be useful to systematise approaches to participatory modelling, and thus quality management (Seidl 2015). Many recent review papers demonstrate the current efforts of the community in this direction. Hare (2011), Voinov et al. (2016), Hedelin et al. (2017), Basco-Carrera et al. (2017) and Jordan et al. (2018) focus on the features, limits and challenges of participatory modelling. Langsdale et al. (2013), Voinov et al. (2018) and Sterling et al. (2019) developed principles and best practices. Bots and Van Daalen (2008), Hare (2011), Barreteau et al. (2013), and Van Bruggen, Nikolic and Kwakkel (2019) propose guidelines for basic design choices and the classification of approaches. Hassenforder et al. (2016), Hedelin et al. (2017) and Voinov et al. (2018) propose extended process description frameworks that can be used for assessment and comparison or process design.

\section{Resource implications}

As for any participatory process, local social capital is an essential resource for planning and organising participatory modelling (identification, selection and mobilisation of participants, relationships with other arenas). In this regard, established relationships and community coleads are crucial in navigating the social and political context (Sterling et al. 2019).

Various capacities are needed in the organising team. Some are generic to participatory processes (participatory engineering skills, knowledge of the context, social and facilitation skills, openness to learn, ability to adjust or even dismiss existing objectives and models) or modelling processes (technical skills to implement and explore models). Specific facilitation and modelling skills are needed to ensure knowledge elicitation and make explicit the diversity of views, issues and propositions that have been recognised by the group, even if they cannot be integrated into the model. These are not widespread capacities and make participatory processes sensitive to personnel changes and difficult to sustainably transfer (Langsdale et al. 2013; Sterling et al. 2019).

Participation and modelling both generate important time constraints, and it might prove difficult to coordinate stakeholders' and modellers' time frames (Hedelin et al. 2017). Depending on the type of model, specific material and software are needed. Finally, additional staff may be required for assistance and observation during workshops, and afterwards for dissemination, monitoring and evaluation.

\section{New directions}

Participatory modelling needs research and innovation to improve its transfer outside the academic world, its impact, and its uptake by local communities or management institutions. Interesting protocols are based on strategic resource minimalist research projects (Landström et al. 2019) or low-tech tools and adaptive workflows that can be used to engage and autonomise practitioners and stakeholders (Ferrand et al. 2017). Artificial intelligence technologies might be useful by partially automating participatory modelling processes (e.g. transforming discourses into models or assisting groups of participants in a process workflow). Web services and tools that could support online modelling activities in large-scale participatory processes or as alternative settings to face-to-face meetings are reviewed in Voinov et al. (2016). 


\section{Case study 13.1: Participatory modelling with cattle breeders in Uruguay}

In Uruguay, nicknamed the 'green desert', the pampa offers a natural pasture where the herds graze freely, providing high-quality meat for export. However, climate change is affecting cattle farming - the primary economic source of this small country. From the 1990 s onwards, droughts have occurred, killing thousands of animals and causing many bankruptcies. In response to these changes, the Instituto Plan Agropecuario (IPA) of Uruguay launched the 'SequiaBasalto' project, which aims to understand the drought phenomena and develop a participatory methodology to improve the adaptive capacities of livestock farmers using the ComMod approach (Barreteau et al. 2003). The objective of the model was to test several management strategies and facilitate communication between livestock farmers and support services. The study was conducted by Bommel et al. (2014). An agent-based modelling approach was chosen for its capacity to integrate various disciplines and types of expertise.

The first version of the model was collectively designed with livestock and grassland specialists from the project. They used unified modelling language (UML) diagrams to specify and share their expert knowledge on pasture growth processes, herd dynamics and farmers' management strategies into a common vision of the model (Figure 13.1A). The resulting model was then implemented on the Cormas platform. This model refined grass growth, herd behaviour and population dynamics. In contrast, farmers' management strategy options were coarse, corresponding to (a) IPA experts' representations of farmers' traditional practices, guided by profit, or (b) recommended best practices, guided by pasture sustainability.

The second stage of the process was to invite farmers to analyse running simulations and the behaviours of the farmer agents. Not surprisingly, the management strategies were the focus of the farmers' criticisms. What was more surprising was that, after discussions based on interactive simulations, farmers, both men and women, engaged in analysing UML activity diagrams (Figure 13.1C))! In fact, farmers were already accustomed to this formalism because, following the recommendation from an IPA researcher, IPA technicians had been using UML activity diagrams to conduct their interviews. The Cormas specialist in the project considered this to be an opportunity to develop and test an executable activity diagram editor into Cormas (Bommel et al. 2016).

In the third stage of the project, farmers participated in hybrid workshops mixing participatory modelling and interactive simulation to make the assessment livelier and more effective. Using the UML activity diagram editor embedded in Cormas, participants were able to generate new management strategies without programming knowledge and directly observe their impacts in simulations. This increased interactivity with the model revealed two interesting features:

1. By being able to modify the agents' behaviour, participants played with the model and better understood its logic. The immediate response of the model to each change increased their understanding of the underlying mechanisms. This triggered debates on how best to deal with droughts. 

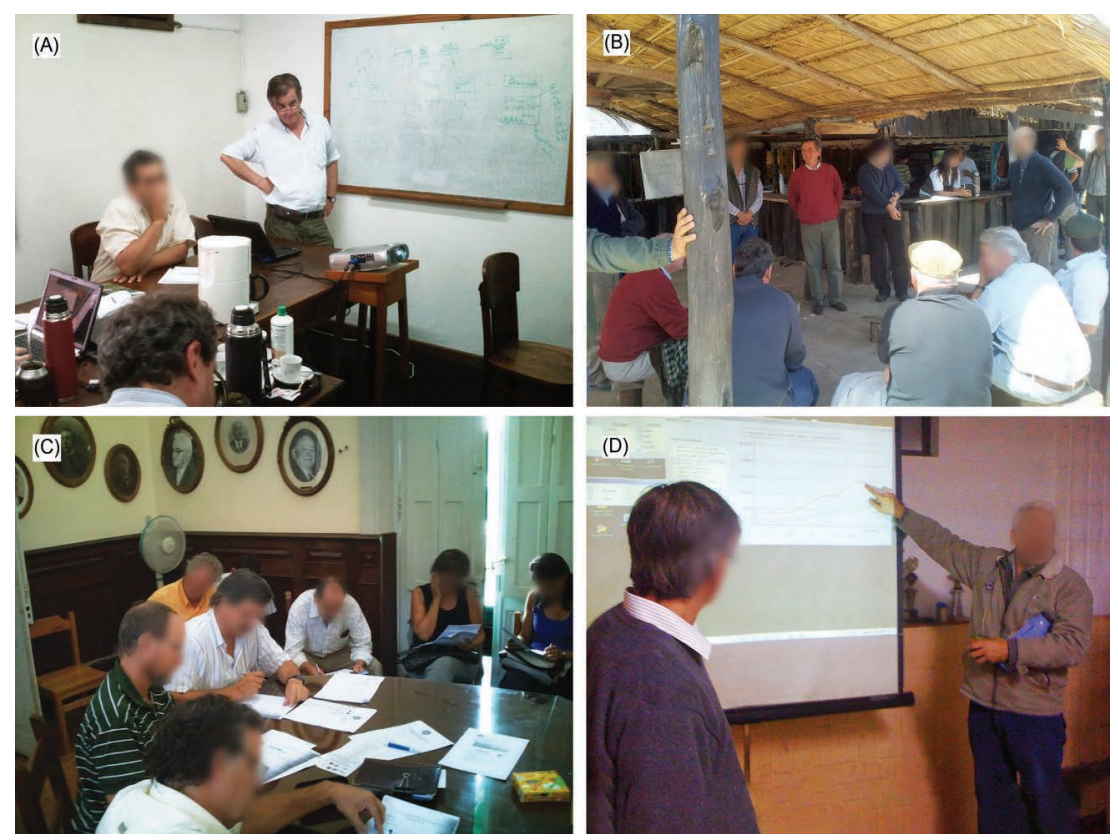

Figure 13.1 (A) Design session with experts, (B) first workshop with producers, (C) evaluation by farmers of the UML diagrams of the model, and (D) a farmer explains a simulation (@ Pierre Bommel)

2. By testing alternative strategies with the UML editor, participants were able to identify some modelling and implementation biases. A strategy they had defined was not producing the result they had expected and they identified an issue with the way some actions of the agents were scheduled in the agentbased model.

The primary objective of this participatory modelling process was to improve knowledge of the livestock system, and indeed, it brought the IPA experts to acknowledge that their recommendations in terms of management had not always been the best. Outside periods of drought, the traditional strategy seemed in fact more economically profitable.

Although originally designed by the experts, the model highlighted the value of different types of knowledge. Beyond the debates it generated, the agent-based model also helped to identify adaptation strategies that seem to improve producers' resilience. Today, most of the farmers and technicians who participated in the workshops continue to experiment with the model. They use it to seek more effective management strategies in normal and drought periods. The Uruguayan government is now using this project as a methodological example to be followed for other development projects. 
A second set of innovations relates to smoothing and tailoring the experience of participatory modelling. Participatory modelling may benefit from a closer collaboration with the fields of design, science communication and human-computer interaction to better design communication elements such as user interfaces, model guides and diagrams (Jordan et al. 2018). Advances in digital and communication technologies provide new forms of visual media for use in participatory modelling (Voinov et al. 2016). There could also be more responsive human-computer interactions to enhance interactions among participants and with the model (Bommel et al. 2018). For a case study where anthropology and arts-based facilitation allowed adjustment to the cultural specificities of participants, see McCarter et al. (2018).

A third set of innovations relates to a better articulation of models among themselves and with real-world processes. Little work has been done on the articulation of different modelling approaches that apply to the same SES (Jordan et al. 2018).

The design science concepts developed by Klabbers (2009) can be used to reflect and design the articulation between a participatory modelling process and the research or decision-making processes with which it is interconnected (Becu 2020). Hedelin et al. (2017) elaborate on organisational integration as a key research question.

\section{Key readings}

Barreteau, O., P. Bots, K. Daniell, M. Etienne, P. Perez, C. Barnaud, D. Bazile et al. 2013. 'Participatory Approaches.' In Simulating Social Complexity: A Handbook (2nd ed), edited by B. Edmonds and R. Meyer, 197-234. Berlin: Springer. doi:10.1007/978-3-540-93813-2_10.

Hare, M. 2011. 'Forms of Participatory Modelling and its Potential for Widespread Adoption in the Water Sector.' Environmental Policy and Governance 21(6): 386-402. doi:10.1002/eet.590.

Van Bruggen, A., I. Nikolic, and J. Kwakkel. 2019. 'Modeling with Stakeholders for Transformative Change.' Sustainability 11(3): 825. doi:10.3390/su11030825.

Voinov, A., K. Jenni, S. Gray, N. Kolagani, P.D. Glynn, P. Bommel, C. Prell et al. 2018. 'Tools and Methods in Participatory Modeling: Selecting the Right Tool for the Job.' Environmental Modelling and Software 109: 232-255. doi:10.1016/j.envsoft.2018.08.028.

Voinov, A., N. Kolagani, M.K. McCall, P.D. Glynn, M.E. Kragt, F.O. Ostermann, S.A. Pierce, and P. Ramu. 2016. 'Modelling with Stakeholders - Next Generation.' Environmental Modelling and Software 77: 196-220. doi:10.1016/j.envsoft.2015.11.016.

\section{References}

Abrami, G., F. Nils, M. Sylvie, C. Murgue, A. Popova, H. de Fooij, S. Farolfi, D. du Toit, and W. Aquae-Gaudi. 2012. 'Wat-A-Game, a Toolkit for Building Role-Playing Games about Integrated Water Management.' International Environmental Modelling and Software Society (IEMSs) - Managing Resources of a Limited Planet. www.iemss.org/society/index.php/iemss-2012-proceedings.

Andersen, D.F., J.A.M. Vennix, G.P. Richardson, and E. Rouwette. 2007. 'Group Model Building: Problem Structuring, Policy Simulation and Decision Support.' The Journal of the Operational Research Society 58(5): 691-694.

Antunes, P., R. Santos, and N. Videira. 2006. 'Participatory Decision Making for Sustainable DevelopmentThe Use of Mediated Modelling Techniques.' Land Use Policy, Resolving Environmental Conflicts: Combining Participation and Multi-Criteria Analysis 23(1): 44-52. doi:10.1016/j.landusepol.2004.08.014.

Barnaud, C., and A. van Paassen. 2013. 'Equity, Power Games, and Legitimacy: Dilemmas of Participatory Natural Resource Management.' Ecology and Society 18(2): 21. doi:10.5751/ ES-05459-180221.

Barreteau, O., G. Abrami, W. Daré, D. du Toit, N. Ferrand, P. Garin, V. Souchère, A. Popova, and C. Werey. 2012. 'Collaborative Modelling as a Boundary Institution to Handle Institutional Complexities in Water Management.' In Restoring Lands - Coordinating Science, Politics and Action: Complexities of Climate and Governance, 109-127. Amsterdam: Springer. 
Barreteau, O., M. Antona, P. d'Aquino, S. Aubert, S. Boissau, F. Bousquet, W. Daré et al. 2003. 'Our Companion Modelling Approach.' Journal of Artificial Societies and Social Simulation 6(2). http://jasss. soc.surrey.ac.uk/6/2/1.html.

Barreteau, O., P. Bots, K. Daniell, M. Etienne, P. Perez, C. Barnaud, D. Bazile et al. 2013. 'Participatory Approaches.' In Simulating Social Complexity: A Handbook (2nd ed), edited by B. Edmonds and R. Meyer, 197-234. Berlin: Springer. doi:10.1007/978-3-540-93813-2_10.

Barreteau, O., F. Bousquet, and J-M. Attonaty. 2001. 'Role-Playing Games for Opening the Black Box of Multi-Agent Systems: Method and Lessons of Its Application to Senegal River Valley Irrigated Systems.' Journal of Artificial Societies and Social Simulation 4(2): 1-5.

Basco-Carrera, L., A. Warren, E. van Beek, A. Jonoski, and A. Giardino. 2017. 'Collaborative Modelling or Participatory Modelling? A Framework for Water Resources Management.' Environmental Modelling and Software 91: 95-110. doi:10.1016/j.envsoft.2017.01.014.

Becu, N. 2020. 'Les Courants d'influence et La Pratique de La Simulation Participative: Contours, Design et Contributions Aux Changements Sociétaux et Organisationnels Dans Les Territoires.' Habilitation à diriger des recherches, La Rochelle Université. https://hal.archives-ouvertes.fr/ tel-02515352.

Bommel, P., N. Becu, B. Bonte, E. Delay, and C. Le Page. 2018. 'Cormas in 10 Years!' Conference_ item. CoMSES Net's Second Virtual Conference. 2018. http://agritrop.cirad.fr/589022.

Bommel, P., N. Becu, C. Le Page, and F. Bousquet. 2016. 'Cormas: An Agent-Based Simulation Platform for Coupling Human Decisions with Computerized Dynamics.' In Simulation and Gaming in the Network Society. doi:10.1007/978-981-10-0575-6.

Bommel, P., F. Dieguez, D. Bartaburu, E. Duarte, E. Montes, M.P. Machin, J. Corral, C. José, P. de Lucena, and H.M. Grosskopf. 2014. 'A Further Step Towards Participatory Modelling. Fostering Stakeholder Involvement in Designing Models by Using Executable UML.' Journal of Artificial Societies and Social Simulation 17(1): 6.

Bots, P.W.G., and C.E. van Daalen. 2008. 'Participatory Model Construction and Model Use in Natural Resource Management: A Framework for Reflection.' Systemic Practice and Action Research 21(6): 389. doi:10.1007/s11213-008-9108-6.

Bouamrane, M., M. Spierenburg, A. Agrawal, A. Boureima, M-C. Cormier-Salem, M. Etienne, C. Le Page, H. Levrel, and R. Mathevet. 2016. 'Stakeholder Engagement and Biodiversity Conservation Challenges in Social-Ecological Systems: Some Insights from Biosphere Reserves in Western Africa and France.' Ecology and Society 21(4): 25. doi:10.5751/ES-08812-210425.

Bousquet, F., and C. Le Page. 2004. 'Multi-Agent Simulations and Ecosystem Management: A Review.' Ecological Modelling 176(3): 313-332. doi:10.1016/j.ecolmodel.2004.01.011.

Celio, E., and A. Grêt-Regamey. 2016. 'Understanding Farmers' Influence on Land-Use Change Using a Participatory Bayesian Network Approach in a Pre-Alpine Region in Switzerland.' Journal of Environmental Planning and Management 59(11): 2079-2101. doi:10.1080/09640568.2015.1120713.

Costanza, R., and M. Ruth. 1998. 'Using Dynamic Modeling to Scope Environmental Problems and Build Consensus.' Environmental Management 22(2): 183-195. doi:10.1007/s002679900095.

Creighton, J.L., and S. Langsdale. 2009. 'Analysis of Process Issues in Shared Vision Planning Cases.' IWR Report 09-R-05. Institute for Water Resources, US Army Corps of Engineers, Alexandria, VA.

Daniell, K.A., I.M. White, N. Ferrand, I. Ribarova, P. Coad, J.E. Rougier, M. Hare et al. 2010. 'Co-engineering Participatory Water Management Processes: Theory and Insights from Australian and Bulgarian Interventions.' Ecology and Society 15(4): 11. www.ecologyandsociety.org/vol15/iss4/art11.

D’Aquino, P., and A. Bah. 2013. 'A Participatory Modeling Process to Capture Indigenous Ways of Adaptability to Uncertainty: Outputs from an Experiment in West African Drylands.' Ecology and Society 18(4): 16. doi:10.5751/ES-05876-180416.

Daré, W., and J-P. Venot. 2017. 'Room for Manoeuvre: Users Participation in Water Resources Management in Burkina Faso.' Development Policy Review 36. doi:10.1111/dpr.12278.

Daré, W., J-P. Venot, C. Le Page, and A. Aduna. 2018. 'Problemshed or Watershed? Participatory Modeling towards IWRM in North Ghana.' Water 10(6): 721. doi:10.3390/w10060721.

Das, B. 2004. Generating Conditional Probabilities for Bayesian Networks: Easing the Knowledge Acquisition Problem. Ithaca: Cornell University.

Dewulf, A., R. Bouwen, and T. Taillieu. 2006. 'The Multi-Actor Simulation "Podocarpus National Park" as a Tool for Teaching and Researching Issue Framing.' SSRN Scholarly Paper ID 915943. Rochester: Social Science Research Network. https://papers.ssrn.com/abstract=915943. 
Düspohl, M., S. Zacharias, and P. Doell. 2012. 'A Review of Bayesian Networks as a Participatory Modeling Approach in Support of Sustainable Environmental Management.' International Journal of Sustainable Development 5: 1-18. doi:10.5539/jsd.v5n12p1.

Etienne, M., D. du Toit, and S. Pollard. 2011. 'ARDI: A Co-construction Method for Participatory Modeling in Natural Resources Management.' Ecology and Society 16(1): 44. doi:10.5751/ ES-03748-160144.

Ferrand, N., G. Abrami, E. Hassenforder, B. Noury, R. Ducrot, S. Farolfi, P. Garin, B. Bonte, S. Morardet, and D. L'Aot. 2017. 'Coupling for Coping, CoOPLAaGE: An Integrative Strategy and Toolbox Fostering Multi-level Hydrosocial Adaptation.' Conference item. Proceedings of the ACEWATER2 Scientific Workshop, Accra, Ghana, 31 October-3 November 2016. http://agritrop.cirad.fr/585578.

Forrester, J., R. Greaves, H. Noble, and R. Taylor. 2014. 'Modeling Social-Ecological Problems in Coastal Ecosystems: A Case Study.' Complexity 19(6): 73-82. doi:10.1002/cplx.21524.

Funtowicz, S.O., and J.R. Ravetz. 1993. 'Science for the Post-Normal Age.' Futures 25(7): $739-755$. doi:10.1016/0016-3287(93)90022-L.

Gray, S., S. Gray, J.L. de Kok, A. Helfgott, B. O’Dwyer, R. Jordan, and A. Nyaki. 2015. 'Using Fuzzy Cognitive Mapping as a Participatory Approach to Analyze Change, Preferred States, and Perceived Resilience of Social-Ecological Systems.' Ecology and Society 20(2): 11. doi:10.5751/ ES-07396-200211.

Halbe, J., C. Pahl-Wostl, and J. Adamowski. 2018. 'A Methodological Framework to Support the Initiation, Design and Institutionalization of Participatory Modeling Processes in Water Resources Management.' Journal of Hydrology 556: 701-716. doi:10.1016/j.jhydrol.2017.09.024.

Hare, M. 2011. 'Forms of Participatory Modelling and its Potential for Widespread Adoption in the Water Sector.' Environmental Policy and Governance 21(6): 386-402. doi:10.1002/eet.590.

Harmonicop Team. 2005. 'Learning Together to Manage Together - Improving Participation in Water Management.' EU Research project report. HarmoniCOP. www.harmonicop.uni-osnabrueck. de/HarmoniCOPHandbook.pdf.

Hassenforder, E., N. Ferrand, J. Pittock, K.A. Daniell, and O. Barreteau. 2015. 'A Participatory Planning Process as an Arena for Facilitating Institutional Bricolage: Example from the Rwenzori Region, Uganda.' Society and Natural Resources August. doi:10.1080/08941920.2015.1054977.

Hassenforder, E., J. Pittock, O. Barreteau, K.A. Daniell, and N. Ferrand. 2016. 'The MEPPP Framework: A Framework for Monitoring and Evaluating Participatory Planning Processes.' Environmental Management Journal 57(1): 79-96. doi:10.1007/s00267-015-0599-5.

Hedelin, B., M. Evers, J. Alkan-Olsson, and A. Jonsson. 2017. 'Participatory Modelling for Sustainable Development: Key Issues Derived from Five Cases of Natural Resource and Disaster Risk Management.' Environmental Science and Policy 76: 185-196. doi:10.1016/j.envsci.2017.07.001.

Hoch, C., M. Zellner, D. Milz, J. Radinsky, and L. Lyons. 2015. 'Seeing is not Believing: Cognitive Bias and Modelling in Collaborative Planning.' Planning Theory and Practice 16(3): 319-335. doi:10. 1080/14649357.2015.1045015.

Hommes, S., J. Vinke-de Kruijf, H.S. Otter, and G. Bouma. 2008. 'Knowledge and Perceptions in Participatory Policy Processes: Lessons from the Delta-Region in the Netherlands.' Water Resources Management 23(8): 1641. doi:10.1007/s11269-008-9345-6.

Hovmand, P.S., D.F. Andersen, E. Rouwette, G.P. Richardson, K. Rux, and A. Calhoun. 2012. 'Group Model-Building "Scripts” as a Collaborative Planning Tool.' Systems Research and Behavioral Science 29(2): 179-193. doi:10.1002/sres.2105.

Htun, H., S.A. Gray, C.A. Lepczyk, A. Titmus, and K. Adams. 2016. 'Combining Watershed Models and Knowledge-Based Models to Predict Local-scale Impacts of Climate Change on Endangered Wildlife.' Environmental Modelling \& Software 84(C): 440-457. doi:10.1016/j.envsoft.2016.07.009.

Jakku, E., and P.J. Thorburn. 2010. 'A Conceptual Framework for Guiding the Participatory Development of Agricultural Decision Support Systems.’ Agricultural Systems 103(9): 675-862. doi:10.1016/j. agsy.2010.08.007.

Jones, N.A., P. Perez, T.G. Measham, G.J. Kelly, P. d’Aquino, K.A. Daniell, A. Dray, and N. Ferrand. 2009. 'Evaluating Participatory Modeling: Developing a Framework for Cross-Case Analysis.' Environmental Management 44: 1180-1195. doi:10.1007/s00267-009-9391-8.

Jordan, R., S. Gray, M. Zellner, P.D. Glynn, A. Voinov, B. Hedelin, E.J. Sterling et al. 2018. 'Twelve Questions for the Participatory Modeling Community.' Earth's Future 6(8): 1046-1057. doi:10.1029/2018EF000841. 
Kelly, R.A., A.J. Jakeman, O. Barreteau, M.E. Borsuk, S. ElSawah, S.H. Hamilton, H.J. Henriksen et al. 2013. 'Selecting among Five Common Modelling Approaches for Integrated Environmental Assessment and Management.' Environmental Modelling and Software 47(September): 159-181. doi:10.1016/j.envsoft.2013.05.005.

Klabbers, J.H.G. 2009. The Magic Circle: Principles of Gaming and Simulation. Rotterdam: Sens Publishers. gbr.pepperdine.edu/book-corner/the-magic-circle-principles-of-gaming-and-simulation3rd-and-revised-edition-by-jan-h-g-klabbers.

Kok, K. 2009. 'The Potential of Fuzzy Cognitive Maps for Semi-Quantitative Scenario Development, with an Example from Brazil.' Global Environmental Change 19(1): 122-133. doi:10.1016/j. gloenvcha.2008.08.003.

Landström, C., M. Becker, N. Odoni, and S.J. Whatmore. 2019. 'Community Modelling: A Technique for Enhancing Local Capacity to Engage with Flood Risk Management.' Environmental Science and Policy 92: 255-261. doi:10.1016/j.envsci.2018.11.009.

Langsdale, S., A. Beall, E. Bourget, E. Hagen, S. Kudlas, R. Palmer, D. Tate, and W. Werick. 2013. 'Collaborative Modeling for Decision Support in Water Resources: Principles and Best Practices.' JAWRA Journal of the American Water Resources Association 49(3): 629-638. doi:10.1111/ jawr.12065.

Le Page, C., and P. Bommel. 2005. 'A Methodology for Building Agent-Base Simulations of Common-Pool Resources Management: From a Conceptual Model Designed with UML to Its Implementation in CORMAS.' In Companion Modeling and Multi-Agent Systems for Integrated Natural Resource Management in Asia, edited by F. Bousquet, G. Trébuil, and B Hardy, 327-350. Los Banos: International Rice Research Institute. http://agritrop.cirad.fr/530538.

Le Page, C., and A. Perrotton. 2017. 'KILT: A Modelling Approach Based on Participatory Agent-Based Simulation of Stylized Socio-Ecosystems to Stimulate Social Learning with Local Stakeholders.' In Autonomous Agents and Multiagent Systems, edited by G. Sukthankar and J.A. Rodriguez-Aguilar, 31-44. Lecture Notes in Computer Science. New York: Springer.

Lynam, T. 2001. 'Participatory Systems Analysis - An Introductory Guide.' Special Report No. 22. Institute of Environmental Studies. Harare: University of Zimbabwe.

McCarter, J., E. Sterling, S. Jupiter, G. Cullman, S. Albert, M. Basi, E. Betley et al. 2018. 'Biocultural Approaches to Developing Well-Being Indicators in Solomon Islands.' Ecology and Society 23(1): 32. doi:10.5751/ES-09867-230132.

Mendoza, G.A., and R. Prabhu. 2006. 'Participatory Modeling and Analysis for Sustainable Forest Management: Overview of Soft System Dynamics Models and Applications.' Forest Policy and Economics 9(2): 179-196. doi:10.1016/j.forpol.2005.06.006.

Metcalf, S.S., E. Wheeler, T.K. BenDor, K.S. Lubinski, and B.M. Hannon. 2010. 'Sharing the Floodplain: Mediated Modeling for Environmental Management.' Environmental Modelling and Software, Thematic Issue on Modelling with Stakeholders 25(11): 1282-1290. doi:10.1016/j. envsoft.2008.11.009.

Nguyen, N.C., and O.J.H. Bosch. 2013. 'A Systems Thinking Approach to Identify Leverage Points for Sustainability: A Case Study in the Cat Ba Biosphere Reserve, Vietnam.' Systems Research and Behavioral Science 30(2): 104-115. doi:10.1002/sres.2145.

Pahl-Wostl, C., M. Craps, A. Dewulf, E. Mostert, D. Tabara, and T. Taillieu. 2007. 'Social Learning and Water Resources Management.' Ecology and Society 12(2): 5. doi:10.5751/ES-02037120205.

Palmer, R.N., W.J. Werick, A. MacEwan, and A.W. Woods. 1999. 'Modeling Water Resources Opportunities, Challenges and Trade-Offs: The Use of Shared Vision Modeling for Negotiation and Conflict Resolution.' WRPMD'99'. doi:10.1061/40430\%281999\%291.

Polhill, J.G., L-A. Sutherland, and N.M. Gotts. 2009. 'Using Qualitative Evidence to Enhance an Agent-Based Modelling System for Studying Land Use Change.' Journal of Artificial Societies and Social Simulation 13(2): 10

Ponta, N., T. Cornioley, A. Dray, N. van Vliet, P.O. Waeber, and C. Garcia. 2019. 'Hunting in Times of Change: Uncovering Indigenous Strategies in the Colombian Amazon Using a Role-Playing Game.' Frontiers in Ecology and Evolution. doi:10.3389/fevo.2019.00034.

Salliou, N., C. Barnaud, A. Vialatte, and C. Monteil. 2017. 'A Participatory Bayesian Belief Network Approach to Explore Ambiguity among Stakeholders about Socio-Ecological Systems.' Environmental Modelling and Software 96: 199-209. doi:10.1016/j.envsoft.2017.06.050. 
Sandker, M., B. Campbell, M. Ruiz-Pérez, J. Sayer, R. Cowling, H. Kassa, and A. Knight. 2010. 'The Role of Participatory Modeling in Landscape Approaches to Reconcile Conservation and Development.' Ecology and Society 15(2): 13. doi:10.5751/ES-03400-150213.

Schlüter, M., B. Müller, and K. Frank. 2019. 'The Potential of Models and Modeling for Social-Ecological Systems Research: The Reference Frame ModSES.’ Ecology and Society 24(1): 31. doi:10.5751/ ES-10716-240131.

Seidl, R. 2015. 'A Functional-dynamic Reflection on Participatory Processes in Modeling Projects.' Ambio 44(8): 750-765. doi:10.1007/s13280-015-0670-8.

Smajgl, A., and J. Ward. 2015. 'Evaluating Participatory Research: Framework, Methods and Implementation Results.' Journal of Environmental Management 157(July): 311-319. doi:10.1016/j. jenvman.2015.04.014.

Smajgl, A., J. Ward, T. Foran, J. Dore, and S. Larson. 2015. 'Visions, Beliefs, and Transformation: Exploring Cross-Sector and Transboundary Dynamics in the Wider Mekong Region.' Ecology and Society 20(2): 15. doi:10.5751/ES-07421-200215.

Smith, C., L. Felderhof, and O.J.H. Bosch. 2007. 'Adaptive Management: Making It Happen through Participatory Systems Analysis.' Systems Research and Behavioral Science 24(6): 567-587. doi:10.1002/ sres.835.

Souchère, V., L. Millair, J. Echeverria, F. Bousquet, C. Le Page, and M. Etienne. 2010. 'Co-constructing with Stakeholders a Role-playing Game to Initiate Collective Management of Erosive Runoff Risks at the Watershed Scale.' Environmental Modelling and Software 25: 1359-1370. doi:10.1016/j. envsoft.2009.03.002.

Star, S.L., and J.R. Griesemer. 1989. 'Institutional Ecology, “Translations” and Boundary Objects: Amateurs and Professionals in Berkeley's Museum of Vertebrate Zoology 1907-1939.' Social Studies of Science 19(3). doi:10.1177/030631289019003001.

Stave, K. 2010. 'Participatory System Dynamics Modeling for Sustainable Environmental Management: Observations from Four Cases.' Sustainability 2(9): 2762-2784. doi:10.3390/su2092762.

Sterling, E., M. Zellner, K. Jenni, K. Leong, P. Glynn, T. BenDor, P. Bommel et al. 2019. 'Try, Try Again: Lessons Learned from Success and Failure in Participatory Modeling.' Elementa: Science of the Anthropocene, February. doi:10.1525/elementa.347.

Tsouvalis, J., and C. Waterton. 2012. 'Building "Participation" upon Critique: The Loweswater Care Project, Cumbria, UK.' Environmental Modelling and Software, Thematic issue on Expert Opinion in Environmental Modelling and Management, 36: 111-121. doi:10.1016/j.envsoft.2012.01.018.

Van Bruggen, A., I. Nikolic, and J. Kwakkel. 2019. 'Modeling with Stakeholders for Transformative Change.' Sustainability 11(3): 825. doi:10.3390/su11030825.

Vennix, J. 1996. Group Model Building: Facilitating Team Learning Using System Dynamics. Chichester: John Wiley and Sons.

Vidal, R.V.V. 2006. 'Operational Research: A Multidisciplinary Field.' Pesquisa Operacional 26(1): 69-90. doi:10.1590/S0101-74382006000100004.

Voinov, A., and F. Bousquet. 2010. 'Modelling with Stakeholders.' Environmental Modelling and Software, Thematic Issue on Modelling with Stakeholders 25(11): 1268-1281. doi:10.1016/j. envsoft.2010.03.007.

Voinov, A., K. Jenni, S. Gray, N. Kolagani, P.D. Glynn, P. Bommel, C. Prell et al. 2018. 'Tools and Methods in Participatory Modeling: Selecting the Right Tool for the Job.' Environmental Modelling and Software 109: 232-255. doi:10.1016/j.envsoft.2018.08.028.

Voinov, A., N. Kolagani, M.K. McCall, P.D. Glynn, M.E. Kragt, F.O. Ostermann, S.A. Pierce, and P. Ramu. 2016. 'Modelling with Stakeholders - Next Generation.' Environmental Modelling and Software 77: 196-220. doi:10.1016/j.envsoft.2015.11.016.

Werick, W.J. 1994. 'National Study of Water Management During Drought: Managing Water for Drought.' IWR Report 94-NDS-8. Alexandria, VA: US Army Corps of Engineers, Water Resources Support Centre, Institute for Water Resources. www.iwr.usace.army.mil/docs/iwr reports/94nds8.pdf. 